\title{
The Financial and Economic Crisis, Its Impacts on the Shipping Industry, Lessons to Learn: The Container-Ships Market Analysis
}

\author{
Bomboma Kalgora, Tshibuyi Mutinga Christian \\ School of Economics and Management, Shanghai Maritime University, Shanghai, China \\ Email: research.kb@outlook.com
}

Received 1 December 2015; accepted 12 January 2016; published 15 January 2016

Copyright (C) 2016 by authors and Scientific Research Publishing Inc.

This work is licensed under the Creative Commons Attribution-NonCommercial International License (CC BY-NC).

http://creativecommons.org/licenses/by-nc/4.0/

(c) () \& 8 pen Access

\begin{abstract}
The container shipping, the important beneficiary and the major element of globalization, has remained a way of moving goods all over the world at an ever-increasing pace since not long ago. With China becoming the world's factory, the industry has known a sustained and rapid growth from year to year. Many among ship owners, bankers, and investors during this period of boom in the shipping industry, become very rich. The availability of cash, with the construction of more technologically advanced ships, with the expansion of ports and the introduction of new shipping services, the cargo capacity in terms of twenty-foot equivalent units (TEU) of the world container fleet, had more than tripled between the years 2000-2009, reaching 12.5 million. But now, the well-known global financial and economic crisis of 2009 had almost overnight suppressed the growth of the container-ships market. In fact, for the first time in the history of the maritime industry, growth has stopped and there is even a steady decline in the rate of containers shipped around the world. In the first six months of the year of the crisis alone, the shipping industry declined by close to $16 \%$ causing huge losses.
\end{abstract}

\section{Keywords}

Container-Ships, Economic Crisis, Freight, Financial Crisis, Market, Shipping

\section{Introduction}

The shipping industry is not immune from an economic recession. This fact was known from the global financial and economic crisis of 2008, which had a strong impact on the shipping market. The shipping is the faithful servant of global trade and a fulcrum of economic growth, facilitating an estimated $90 \%$ of global trade volume 
[1]. The world is more dependent on it than ever. As such, the industry is influenced by factors such as economy, trade, production, consumption, politics, financing and technology that drive the demand and supply of manufactured goods, raw materials and shipping services. A drastic decline of freight rates and time charter or in the fore mentioned factors, is almost immediately visible throughout the shipping market. For the first time since 1982, the world's GDP decreased by $2.2 \%$ while the international trade rate dropped by $14.4 \%$ [2]. Therefore, the curtailment of economic activities and consumption has resulted in a drop of trade volumes and low demand for maritime transport. Just as the shipping industry enjoyed a spectacular booming during the mid-2000s when the global economy performed well; its fortunes were also inextricably related to the recent slump in the global economy. It is therefore not surprising that the shipping market has suffered along with the global financial and economic crisis.

The 2008 crisis had been the longest and most severe downturn for the modern merchant in the history of container-ships market. The freight rates in key container shipping trades, have slumped to nearly all-time lows, as ship owner struggled with low demand for their vessels. At this point, the global financial and economic crisis is wreaking havoc on container-ships market; the demand and prices have collapsed and ports are filled up with fleets of empty freighters.

The crisis has fueled a cut-throat competition, and not all shipping line companies can survive. This paper aimed to present the impacts of the global financial and economic crisis of 2008 on the container-ships market and mainly drew lessons from them. The recent fall in freight rates is a challenge to ship-owners, ship-operators and analysts of the maritime economy. The crucial task is to succeed in employing the ship in a way to achieve the break-even point, or at least to cover the variable operating costs in a short time.

The remainder of the paper is structured as follows. Section 2 discusses the booming period of container-ships market, and the harbinger of the crisis. Section 3 investigates the factors worsening the crisis in the container shipping sector. Section 4 enumerates the consequences of the financial and economic crisis on that segment of the shipping industry. Section 5 develops the opportunities birthed from the crisis. Section 6 suggests the possible adjustments during the crisis in the container-ships market. Finally, Section 7 concludes.

\section{Shipping Industry on the Eve of the Crisis}

\subsection{The Period of Booming}

During the "golden age" of the shipping industry, freight rates in all the major shipping trade were heading skyward. The industry and particularly, the containers sector were awash with cash; banks were eagerly lending huge amounts at very competitive rates to ship owners who went on an expansion binge and aggressively enlarging their fleet. Ports were enjoying record throughputs, and thanks to the insatiable demand for all kinds of goods and materials, largely fueled by the spectacular growth in developing economies namely, BRIC countries (Brazil, Russia, India and China).

Between 2002 and 2004 as shown in Table 1, demand for containerized trade grew faster than the supply of container carrying capacity, so the industry ordered new tonnage. Usually, the new tonnage is delivered in a period time of two to three years, and from 2006, the supply of container ships on the market has been growing even faster than the demand. As the vessels ordered few years passed, continued to be delivered by the world's shipyards, this led to a tremendous expansion of container ships fleet's capacity. Thereafter, between January 2009 and January 2010, the world fleet's total container carrying capacity increased by 5.7\%; the difference in growth rates in 2009, amounted to an astounding 15 percentage points [3].

\subsection{Hint Signs of the Crisis on Container-Ships Market}

The global financial and economic recession of 2008 has resulted in a sharp downturn of the economy and the shipping market. This has directly led to a rapid fall in demand for transport and related services. For example, throughputs in the world's largest container ports; Singapore and Shanghai, decreased by $13.5 \%$ and $11 \%$ respectively in 2009 [4]. Added to the fact that earlier in June of the same year, the China Containerized Freight Index showed that Chinese exports were down $21.4 \%$ year on year, ever since China became the world's factory. World-class ports including the port of Hamburg, Los Angeles/Long Beach and New York, have registered significant slowdowns compared to year 2008.

According to ECLAC (2009) [5], the United Nation Economic Commission for Latin America and the Carib- 
Table 1. Growth of demand and supply in container shipping 2000-2010 (annual growth rates).

\begin{tabular}{ccccccccccccc}
\hline & 2000 & 2001 & 2002 & 2003 & 2004 & 2005 & 2006 & 2007 & 2008 & 2009 & 2010 \\
\hline Demand & 10.7 & 2.4 & 10.5 & 11.6 & 13.4 & 10.6 & 11.2 & 10.9 & 4.4 & -9.7 & 5.2 \\
Supply & 7.8 & 8.5 & 8.0 & 8.0 & 8.0 & 10.5 & 13.6 & 11.7 & 10.9 & 5.2 & 5.2 \\
\hline
\end{tabular}

Source: UNCTAD Review of Maritime Transport 2009, updated with data from Clarkson Container Intelligence Monthly January 2010. Year 2010 is a Clarkson Research Services forecasting.

bean, the activity at the major region's ports fell by $11.2 \%$, less than the worldwide figures. Between July 2008 and May 2009, the number of containers arriving at Charleston, in South Carolina and one of the largest ports in the US, from the northern European regions the point of departure for German goods, declined by about 100,000. The total volume at the port has dropped by almost $18 \%$ [6]. This decline is attributed to low demand in Europe for manufactured goods on the back of the euro zone crisis.

\section{Factors Aggravating of the Crisis on Container-Ships Market}

\subsection{New Container Ships Orders}

The boom of the last few years was also due in large part to an abundance of available cash at low interest rates. Thus spurred by high yields, investors and banks have pumped hundreds of billions into the container shipping business, for then considered to be extremely profitable. Consequently, many companies in this market sector have heavily invested in new ships building at the height of the economic boom in 2006 and 2007. By the time these ships were delivered, demand for shipping goods had crashed, leaving the market with a surplus of very modern, very large vessels, and a greatly reduced order book.

Shipping companies such as Maersk were affected during the container-ships market recession as they ordered new container ships when the industry was booming. The orders for new container ships on the shipyards' books represented a total capacity of 5.3 million TEUs, for about $50 \%$ more than current worldwide container fleet capacity. The delivery of new buildings with huge capacity has exacerbated the oversupply situation in already beleaguered trades.

\subsection{Overcapacity}

In 2012, volume of imports in Europe dropped once again below the 2009 level. This caused an even larger overhang of capacity. In a nutshell, even without the 2008 crisis, the huge order book of new ships would have by few years ahead led to an oversupply of tonnages and a corresponding decline in vessel prices; and this has been made worse by the economic downturn. The containers ships fleet is forecasted to continue a steady growth over the next four to five years, and most of this growth is on account of ships that can carry more than 10,000 TEU.

\section{Consequences of the Crisis on Container-Ships Market}

The demand for container shipping services has known a dramatic slump and the freight rates have suffered a sharp drop. There was never shortage of cargo in the past, meaning prior 2009, but that's no longer the case after the crisis. The fall of consumption in the West and of production in the East, resulted to the global container fleet enormous cargo capacity to be no longer filled. The latter could not be without effect on the market of container transport.

\subsection{A Domino Effect}

At this point of the crisis, shipping line operators were no longer able to pay for their chartered ships; during the same time, the owners of the chartered ships and the shipping funds were no longer able to afford to service their debts to the banks. This has led many of the banks in maritime transport to bankruptcy. For instance, HSH Nordbank, largest bank lender for the shipping industry in the world, had outstanding ships construction loans worth 45 billion US\$ on its book. Without adequate revenues for chartered ships, shipping companies would be unable to service their bank loans, thus forcing the banks to be more hesitant to issue credit. 


\subsection{Stop of Leasing Contracts}

Most of shipping line operating in container shipping services, which hadn't a vast naval fleet were obliged to return back a large number of the chartered vessels to their owner by simply stopping contracts. This was the case of Hapag-Lloyd which got rid of ships it leased. The German shipping company owned, at the time of the crisis, just about half of its naval fleet of 128 container ships. The other half was leased and for this reason, was to be jettisoned more quickly. It is thus that about 30 chartered container ships were returned to their owners by Hapag-Lloyd. The others shipping companies had not renewed their charters either expired or about to expire; among them were CMA a French shipping company, and MSC a Swiss base company, just to mention few of them.

\subsection{Price Competition}

The largest shipping companies could have probably face off the crisis, but there remained a bloodbath among the smaller ones. During this financial and economic crisis, financially strong shipping companies have fueled the price war even further to gain more market share.

\subsection{Jobs Losses}

In fact, to mitigate or even counter the effects of the crisis, measures were taken; the shipping companies have laid up vessels and laid off workers around the world. Regardless, there were substantial cutbacks, job cuts and salary reductions were unavoidable, mostly due to the slowdown of the freight rate.

On ship builders' side, as the orders for new buildings were decreasing as shown in Figure 1, shipyards around the world were running at only $30 \%$ of their capacity, thus cut down the workers' salaries or worse laying off their workers were the foreseeable solutions to lessen the crisis impacts. Some years ago, the DSF (Danish Ship Finance) has predicted that about $4 \%$ of the world's shipyards would have closed or gone inactive in 2012 and in the time frame of 2013 to 2014, several yards would be at short of orders [7].

\subsection{Drop of the Freight Volume}

The brand new giant ships delivered at the peak of the financial and economic crisis, were too much big for the transported cargos, and they often sailed half empty if at all. The container shipping sector once one of the biggest beneficiaries of globalization, was then threatened to turn into one of its chief casualties.

\subsection{Debts, Financial Losses and Bankruptcy}

The shipping line operators have suffered alone to the industry, a combined loss of about 20 billion US\$ in 2009. The traditional German shipping company Hapag-Lloyd's lost more than 300 million US\$ in the first quarter of 2009 and needed close to 2.5 billion US\$ to stay afloat.

In terms of the freight rate, shipping companies at the time of the crisis were charging about 500 US\$ to ship

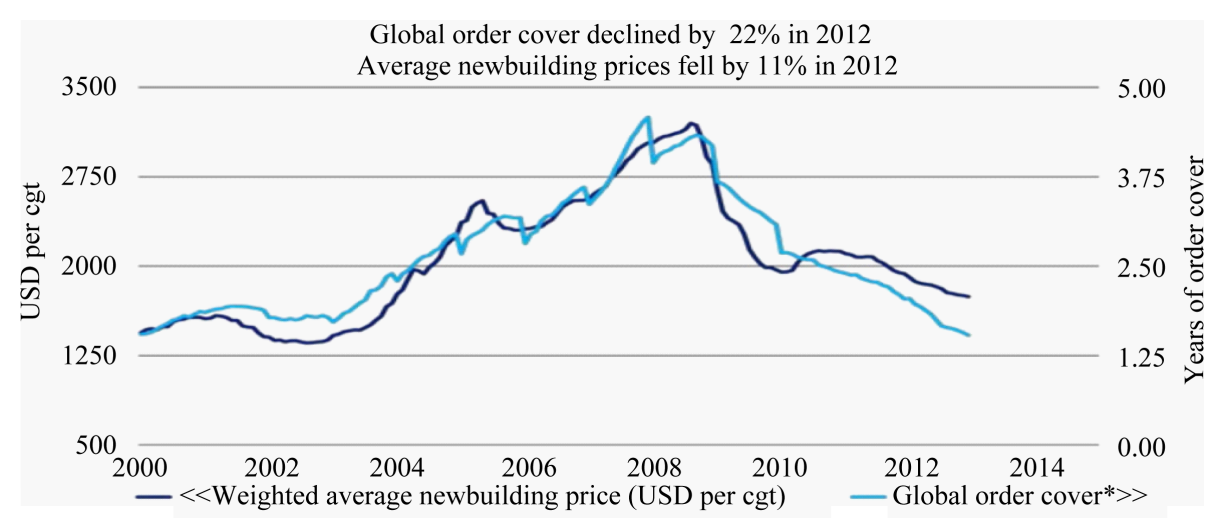

Figure 1. Global newbuilding order cover (figure caption). Source: Shipping Market Review, April 2013. Clarksons, Danish Ship Finance. Page 10, figure SB.1. 
one container from Asia to Europe, counting about 300 US\$ less than they needed to cover their costs. Prior the crisis, shipping companies were charging more than 1500 US\$ per container [8].

The Danish shipping company Maersk, owned by an oil and gas company also lost 373 million US\$ in the first quarters of the beginning of the crisis. Others, like Singapore-based NOL, for example, posted 245 million US\$ of losses, while South Korea’s Hanjin lost 110 million US\$ [9].

\section{Financial and Economic Crisis and Its Opportunities}

However, the financial and economic crisis didn't obscure the opportunities, rather, bright spots were still available in this time of trouble of the shipping industry.

The crisis has created opportunities for China ports to catch up with its foreign competitors. For this reason, current plans call for Yangshan Port in Shanghai, to have 30 terminals capable of processing 15 million containers a year, by 2020. The northern city of Tianjin has established a shipbuilding investment fund following the crisis. Its main goal is to acquire shares in ailing shipyards, support mergers and acquisitions, and buy ships for which orders were cancelled or forfeited. This is part of China's strategy to help its shipyards survive the crisis.

The ship-recycling industry experienced its largest growth period in history, after the crisis saw rates for many vessels types collapse. With a three-fold increasing in ship-scrapping expected globally the year following the crisis, more than 1000 ships were destined for the breakers' yards. There were fears that existing yards at that time could not handle the workload [10].

More the costs for maritime transport services were dropping, the more it made sense that the Western companies outsource their productions, to other parts of the world. This profited to developing countries where labor cost are lower.

\section{Possible Adjustments in Time of Crisis}

More often, the freight rates and second-hand vessel prices react immediately to a change in the supply and demand balance. Five ways by which the container-ships market, and at some extents the shipping industry, can adjust the industry's supply to a decline in demand while still saving costs.

\subsection{Reduce Sailing Speed}

Shipping companies can reduce sailing speeds and thereby the fuel consumption to cope with the drop in freight rates over the last few years. Kirschbaum E. (2008) [11] estimated that a 10\% reduction in speed can lead to a $25 \%$ reduction in fuel consumption.

The slow steaming means that the voyage speed of ships is reduced, which then makes it necessary to employ a larger number of ships to maintain the same frequency. For example, employ nine or ten vessels on a service that usually only requires eight ships; this option has two main potential advantages known as, the diminishing needs to lay off ships, and, saving fuel. Consequently, even though a low speed implies longer voyages, extra operating costs, charter costs, interest costs and other monetary losses, slowing down still pays off [12].

\subsection{Withdrawal of Existing Tonnage from Service}

To reduce loading capacity, ships are being decommissioned, and they better lie at anchor, unused, in ports, estuaries and bays around the world. Many surplus vessels are not effectively deployed and are instead laid off or idle. As of early 2010, 12\% of global container carrying capacity was idle and anchored at different harbors [13].

\subsection{Terminate or Postpone Existing Orders at the Shipyards}

The numerous deliveries of new building ships in process are to be postponed and could less probably be cancelled as shipyards would not agree to lose the business deal completely.

Since the beginning of the crisis, many orders at the world's shipyards have been rescheduled. The specialized shipping press Fairplay International Shipping Weekly, reported a "dearth of new orders with the renegotiation of existing contracts taking up more of the time of ships builders than new queries" [14]. The activities related to the container shipping in 2009 have focused primarily on the restructuring of existing order books and 
as possible the cancellations and the renegotiations of existing deals became increasing issues [15]. Accordingly, the forecasts for delivered vessels were adjusted downwards each month.

\subsection{Stop New Tonnage Orders}

Orders of new ships have to practically come to a standstill. In 2007, 535 containership vessels were contracted, 208 units were ordered in 2008, yet in 2009 there were only two new orders [16].

\subsection{Demolitions}

The ultimate option could resort in the demolition of the old ships of the naval fleet which due to the very high maintenance costs are becoming expensive to shipping companies to operate in time of crisis.

As the prices for scrap metal are very low, many vessel owners prefer to hold on for a better time ahead. They lay their ships at anchor rather than scrapping them. The demolition of existing tonnages will not be enough to compensate for the downturn in demand and for new tonnages that are still leaving the world's shipyards to flood the market [17].

\section{Conclusions}

The global financial and economic crisis has significantly affected the container-ship market and the shipping industry as a whole. The combination of low demand for container-ship services and the persistent entries of new tonnage into the shipping market have resulted in a severe overcapacity.

Time charters rates because of the reduced speed of vessels, and freight rates, have dropped drastically due to the poor demand of cargo. Furthermore, these falls are quicker than the declination of global exports, meaning that at some point of time, the elements of negative expectations arising from the global financial and economic crisis could have had also the psychological effects on the container-ship market. The same psychological effects have also influenced the oil price. This market which can be easily affected by a range of complex factors such as production, consumption, trade, politics, economy, financing, technology and so on, has a delicate cycle prediction.

Nevertheless, analysts at the UNCTAD predict that there will be pressure on markets in next coming years [18], due to a lingering overcapacity. The GSCC (Greek Shipping Co-Operation Committee) in its annual report 2012-2013 [19] wasn’t optimistic either. The container-ship lines seem to be continually oversupplied, despite the fact that conventional shipping finance is still not easily accessible. Meanwhile, a tidal wave of private equity and hedge fund investment has meant that the world shipyard order books have increased remarkably to the extent where the vessels oversupply will reach 2015 and even last for another 2 or 3 more years, with very little hope of sustained growth. Volatility is the name of the game in this industry, and the peaks will always follow the troughs of economic climate and trade trends. Despite hopes that level of global trade is recovering due to US financial recovery and the apparent economic stability of the Euro-zone, it can take a period of time for the chronic overcapacity of the container-ships market to improve. The shipping industry and in particular, the container-ships market must be viewed with a long-term lens to put its prospect in the right context of the world's economy.

\section{References}

[1] UNCTAD (2008) The Modal Split of International Goods Transport. Transport Newsletter, No. 38, 14.

[2] World Bank (2010) Global Economic Prospects 2010. The World Bank Publication, Washington DC, 4.

[3] Fleet Statistics (2010) Containerization International On-Line. www.ci-online.co.uk

[4] Hoffmann, J. (2010a) Shipping out of the Economic Crisis. The Brown Journal of World Affairs, 16, 122.

[5] ECLAC (2009) The Economic Crisis And The Maritime and Port Sector. Conference on Facilitation of Trade and Transport in Latin America and Caribbean, Santiago of Chile, 2009, 7.

[6] Christopher, S., Alexander, J., Thomas, S. and Wieland, W. (2009) The Container Crisis: Shipping Industry Fights for Survival. Bloomberg Business Journal. http://www.businessweek.com/globalbiz/content/aug2009/gb20090811 320246.htm

[7] Christopher, R., Brian, T., Kenneth, L.R., Stinus, N. and Ninna, M.K. (2013) Shipping Market Review. Danish Ship 
Finance, 17-22.

[8] UNCTAD (2009) Review of Maritime Transport 2009. United Nations Publication, Geneva, 98.

[9] Joseph, B. (2010) Carriers Move Full Speed into Slow Steaming. The Journal of Commerce, Maritime News. http://www.joc.com/maritime-news/carriers-move-full-speed-slow-steaming_20100112.html

[10] Lloyd's List Ports of the World (2008) Lloyd's List Intelligence.

[11] Kirschbaum, E. (2008) Harnessing Kite Power to a Ship. International New York Times, 20 January 2008. http://www.nytimes.com/2008/01/20/business/worldbusiness/20iht-ship.1.9349041.html?_r=0

[12] UNCTAD (2008) Fuel Prices, Transport Costs and the Geography of Trade. UNCTAD Transport Newsletter, No. 39, 2nd Quarter 2008 Published by UNCTAD Trade Logistic Branch, DTL, Palais des Nations, Geneva.

[13] Hoffmann, J. (2010b) Shipping out of the Economic Crisis. The Brown Journal of World Affairs, 16, 125.

[14] Fairplay International Shipping Weekly (2009) LNG Shipping. Fairplay Publications Limited, 366, 14-27.

[15] Clarkson Research Services (2009a) Container Intelligence Monthly. Clarkson Shipping Intelligence Network, 15-16.

[16] Clarkson Research Services (2009b) Container Intelligence Monthly. Clarkson Shipping Intelligence Network, 10.

[17] Clarkson Research Services (2010) Container Intelligence Monthly. Clarkson Shipping Intelligence Network, 39-41.

[18] UNCTAD (2010) Successful Trade and Development Strategies for Mitigating the Impact of the Global Economic and Financial Crisis. United Nations Trade and Development Commission, Geneva.

[19] GSCC (2013) Annual Report 2012-2013. The Baltic Exchange, 38 St. Mary Axe, London. 